TWENTIETH-CENTURY SUSPENSE 


\title{
Twentieth-Century Suspense
}

\section{The Thriller Comes of Age}

Edited by

\author{
CLIVE BLOOM
}

Lecturer in English, Middlesex Polytechnic

Palgrave Macmillan UK 
ISBN 978-0-333-47592-8 ISBN 978-1-349-20678-0 (eBook)

DOI 10.1007/978-1-349-20678-0

(C) Editorial Board, Lumiere (Co-operative) Press Ltd, 1990

Softcover reprint of the hardcover 1st edition 1990 978-0-333-47591-1

All rights reserved. For information, write:

Scholarly and Reference Division,

St. Martin's Press, Inc., 175 Fifth Avenue,

New York, N.Y. 10010

First published in the United States of America in 1990

ISBN 978-0-312-03708-6

Library of Congress Cataloging-in-Publication Data

Twentieth-century suspense: the thriller comes of age / edited by Clive Bloom.

p. $\quad \mathrm{cm}$ - (Insights).

'First published in the United States of America in $1990^{\circ}-\mathrm{T}$.p. verso.

ISBN 978-0-312-03708-6

1. Detective and mystery stories. English - History and criticism.

2. Detective and mystery stories, American - History and criticism.

3. English fiction - 20th century - History and criticism.

4. American fiction -20th century - History and criticism.

I. Bloom, Clive. II. Series: Insights (New York, N.Y.)

PR888.D4T83 1990

89-37805

$823^{\prime} .087209091-\mathrm{dc} 20$

CIP rev. 
For Susan who likes to know whodunit 


\section{Contents}

Preface and Acknowledgements ix

Notes on the Contributors $\quad \mathbf{x}$

1 The Immorally Rich and the Richly Immoral: Raffles and the Plutocracy

Nick Rance

2 West is East: Nayland Smith's Sinophobia and Sax

Rohmer's Bank Balance

Clive Bloom

3 Fear's Keen Knife: Suspense and the Female Detective, 1890-1920

Gwen Williams

4 A Society of Murderers Run on Sound Conservative Lines: The Life and Times of Sapper's Bulldog Drummond

Hans Bertens

5 The Novels of Leslie Charteris

Helena Blakemore

6 Ordeal by Analysis: Agatha Christie's The Thirteen Problems

Gary Day

7 Dorothy Sayers: The Masks of Lord Peter Valerie Pitt

8 Elizabeth Bowen's Stories of Suspense J. A. Morris

9 But One Isn't Murdered: Elizabeth Bowen's The Little Girls

Sandra Kemp 
10 Fifty Million Copies: The Fiction of Dennis Wheatley

Christopher Bentley

11 Margery Allingham and Reader Response

Sue Asbee

12 The View from the Rear Window: The Fiction of Cornell Woolrich
A. Robert Lee

13 Hitchcock and the Mechanics of Cinematic Suspense

\section{Lez Cooke}

14 Grace under Pressure: Reading Alistair MacLean

203 Brian Docherty

15 Elizabeth Jenkins: Perhaps the History Woman Ian MacKillop

16 Feminist Detective Fiction

Maggie Humm

17 The Gentleman's Excuse-me: The Male Apologist and the Experience of Realism in James Herbert's The Magic Cottage

Andrew Smith

Index 


\section{Preface and Acknowledgements}

This volume contains seventeen critical essays on a selection of the most influential and most interesting suspense writers of the twentieth century. From the glittering world of Raffles to the domestic terror of The Magic Cottage, and from the heroics of Bulldog Drummond to the dogged pursuits of Miss Marple, this volume traces a variety of suspense writers: those well known, such as Agatha Christie, Dennis Wheatley and Dorothy L. Sayers, and those less well known, Elizabeth Bowen, Elizabeth Jenkins and the 'new wave' feminist thriller writers of today and the halfforgotten women detective writers of the early part of this century. Also included is Alfred Hitchcock (British suspense in a Hollywood setting) and the work of Cornell Woolrich (Gothic writing in an American world).

This volume is the companion of Nineteenth-Century Suspense: From Poe to Conan Doyle, American Crime Fiction: Studies in the Genre, American Horror Fiction: From Brockden Brown to Stephen King, and the forthcoming Literature and Imperialism and Spy Thrillers. As such it forms part of a unique critical collection dedicated to the study of popular and non-canonical literature. Elsewhere amongst these books the reader can find studies of such names as Stephen King, Raymond Chandler, James M. Cain, Robert Bloch, Arthur Conan Doyle, Rudyard Kipling, Ian Fleming, John Buchan and dozens more. The Insights series is dedicated to the study of neglected aspects of modern culture and the critically neglected literature of the popular imagination.

I should like to acknowledge the help of James Herbert, Leslie Charteris, Valery Rose, Andrew Coleman, Clare Hudson and Sarah Roberts-West in the preparations of this volume and, as always, Lesley Bloom for her patience and suggestions. 


\section{Notes on the Contributors}

Sue Asbee teaches at Queen Mary College, London University. She wrote her Ph.D. thesis on Flann O'Brien, and has published work on Virginia Woolf and Mary Lavin.

Christopher Bentley has published extensively on English and American literature from the seventeenth to the twentieth centuries, and on the history of medicine. He has taught in British, Canadian and Australian universities and now lectures at the University of Sydney.

Hans Bertens is Head of the Department of English and American Literature at the University of Utrecht, in The Netherlands. He has published widely and is an acknowledged expert in postmodernist literature and theory.

Helena Blakemore recently completed a master's degree at the University of London. She is the co-editor (with Maxim Jakubowski) of Rock and Roll and its Culture.

Clive Bloom is General Editor of the Insights series and is the author of two books: The Occult Experience and the New Criticism and Reading Poe, Reading Freud: The Romantic Imagination in Crisis.

Lez Cooke is an Associate Lecturer in Film and Media Studies at Barnet College of Further Education. He has written articles on film and cultural studies for Movie and Screen as well as producing study materials for the British Film Institute.

Gary Day is the editor of Perspectives on Pornography (with Clive Bloom) and Readings in Popular Culture: Trivial Pursuits? He currently teaches drama in the south of England.

Brian Docherty is the editor of American Crime Fiction and American Horror Fiction. He is currently completing his doctoral research in modern American poetry at the University of Essex. 
Maggie Humm is Co-ordinator of Women's Studies at North-East London Polytechnic. She has published a number of articles and essays as well as two books on a wide range of feminist issues.

Sandra Kemp lectures in English literature at the University of Glasgow. She has published work on Kipling and is currently working on The Oxford Companion to Edwardian Fiction.

A. Robert Lee is Senior Lecturer in American Literature at the University of Kent. He has edited ten volumes in the Vision Critical Series on American Literature, broadcasts with the BBC, reviews for The Listener and is editor of the Everyman Moby Dick.

Ian MacKillop is Senior Lecturer in the Department of English Literature at the University of Sheffield. He is the author of The British Ethical Societies.

J. A. Morris teaches at Brunel University. He has published widely and is an acknowledged expert on George Orwell.

Valerie Pitt is the former Head of Humanities at Thames Polytechnic. She has written on a variety of subjects and is a lay member of the Synod of the Church of England.

Nick Rance is a Lecturer in English at Middlesex Polytechnic and is the author of The Historical Novel and Popular Politics in NineteenthCentury England. He is now preparing a book on Wilkie Collins.

Andrew Smith is a graduate student with research interests in popular culture. He is a contributor to Readings in Popular Culture: Trivial Pursuits?

Gwen Williams lectures in English at the Middlesex Polytechnic. Her research interests are the work of Charles Dickens and nineteenth-century popular fiction. 